\title{
平成16年新潟県中越地震における地すべり地形斜面の再滑動の実態 と移動・堆積特性 \\ Geomorphic analysis of the mobility and deposition characteristics of the old landslides reactivated by the 2004 Mid-Niigata Prefecture Earthquake
}

\author{
森脇 寛 ${ }^{a) *}$ ・佐々木良宜 ${ }^{a)}$ \\ Hiromu MORIWAKI and Yoshinori SASAKI
}

\begin{abstract}
The 2004 Mid-Niigata Prefecture earthquake (M6.8) triggered a large number of landslides around the epicenter region. This region geologically consists of Neogene mudstone and sandstone, and is typical landslide-prone area. In this earthquake, many old landslides were reactivated and caused great damages. The initiation and the movement of these landslides were investigated by means of field survey and comparison of the landslide distribution maps, which were made before and after the earthquake. It was found that both old and new landslides were remarkably distributed on slopes facing to the west controlled by the geological structure in this region. Approximately half of the new landsides were occurred on the slopes of old landslides, but most of them were partial slides and only five percent of the new landslides was recognized as the reactivated slide of the entire old landslide masses. Topographic analysis on the entirely reactivated landslides showed that both the first slides (old landslides) and the second slides (reactivated ones) slid with less difference in their width and length. Equivalent coefficient of friction H/L (H : runout height; L : horizontal runout distance) for the second landslides was proportional to the slope of their source area as well as that of the first slides, even if the second landslides have higher mobility than the first ones.

Key words : old landslide, earthquake-induced landslide, reactivation, equivalent coefficient of friction, mobility

\section{和文要旨}

2004年10月23日に発生した平成16年新潟県中越地震（M6.8）により，新潟県旧山古志村周辺では地すべり・崩壊が多発し，大き な被害を受けた。本地域は第三紀層地すべりと呼ばれる地すべりの多発地帯で, 過去に滑動した痕跡を示す地すべり地形斜面の再 滑動も多く見られた。その実態と運動特性を明らかにするために, 旧山古志村を中心に現地調査ならびに地震発生前後の地すべり 分布図を用いて地形解析を行った。その結果，地すべり地形斜面も今回の地震により発生した地すべり・崩壊も当地域の地質構造 を反映して概して西向きの斜面に卓越していることがわかった。また，今回の地震で発生した地すべり・崩壊数の約半数近くは地 すべり地形斜面で発生している。しかし，そのほとんどが部分的な再滑動で，地すべり土塊全体が再滑動した地すべりは地震で発 生した地すべり・崩壊総数の約 $5 \%$ であった。さらに, この地すべり土塊全体が再滑動した地すべりを抽出し, その変動量と地す ベり地形斜面形成時の変動量を比較検討したところ，両者とも移動方向，幅方向にはそれほど伸縮・拡散しないで移動したこと， ならびに地すべり土塊の流動性を示す等価摩擦係数（最大移動高／最大水平移動距離）については，再滑動した地すべりのほうが 地すべり地形斜面形成時の運動に比べて流動性が高いが，どちらも崩壊源の斜面勾配と比例関係にあることが明らかになった。 キーワード：地すべり地形，地震時地すべり，再滑動，等価摩擦係数，流動性
\end{abstract}

\section{1. はじめに}

2004年10月23日17時56分，新潟県中越地方を中心に $\mathrm{M}_{\mathrm{JMA}} 6.8$ の地震（平成16年新潟県中越地震）が発生した。 そのため, 旧山古志村（2005年 4 月 1 日に中之島町, 越 路町, 三島町, 小国町とともに長岡市と合併し, 長岡市 となる)，小千谷市，長岡市，川口町では地すべりや斜 面崩壊が多発し，甚大な被害を被った。とりわけ，旧山 古志村では村の中心を南北に流れる芋川沿いの寺野地区 や東竹沢地区などで大規模な地すべりが発生し，川の流 れを堰止めたため, 点在する集落が水没するなど二次的 被害を受けた。著者らの現地調査によると, この芋川を 堰止めた地すべりをはじめ，いくつかの比較的大きな地 すべりは，過去に地すべり活動があった痕跡を地形的に 示している斜面（以下，地すべり地形斜面と呼ぶ）で発 生していることが明らかになった。

連絡著者/corresponding author

a) 独防災科学技術研究所

National Research Institute for Earth Science and Disaster Prevention

テ305-0006 つくば市天王台3-1

Tennodai 3-1 Tsukuba-shi, Ibaraki, 305-0006, Japan
地すべり地形斜面の再滑動による土砂桨害が指摘され たのはこれが初めてではない。たとえば, 1982年 8 月奈 良県西吉野村和田地すべり（米谷ら，1983）をはじめ, 1997年 5 月秋田県鹿角市澄川地すべり（大八木・池田, 1998)，2001年 7 月秋田県五城目町富津地すべり, 2005 年 4 月石川県羽咋市福水地すべり（防災科学技術研究所, 2006a）などいくつか報告されている。これらの報告事 例だけを見ると，地すべり地形斜面はすべて危険斜面と して認識されがちであるが，必ずしもすべての地すべり 地形斜面が不安定であるというわけではない。地すべり 地形斜面は斜面土層の平衡が破壊して移動・停止した結 果，形成された地形であるから，基本的には安定してい るという考えもある。今回の地震で再滑動しなかった地 すべり地形斜面も数多く存在する。

この地すべり地形斜面の安定問題については，これま で報告された再滑動事例が散発的に発生しているため, 統計的あるいは定量的な解析による議論が十分になされ てこなかった。地すべり地形斜面が非地すべり地形斜面 
に比較して，再滑動の危険度が高いかどうかを結論付け るには，同一の地質分布地域でほぼ同じ強度を有する地 震動や降雨条件下での発生頻度の検証が必要である。今 回の地震により地すべり・崩壊が多発した旧山古志村は もともと「第三紀層地すべり」と呼ばれる地すべりの多 発地帯で，地すべり地形斜面も密に分布しているところ である。佐藤ら（2005）は今回の崩壊・地すべり発生箇 所における第三紀層を構成する個々の岩質の有意性は見 当たらないという報告をして抢り，地すべり地形斜面の 再滑動率の評価を行うには条件的に都合が良い地域であ る。また，現実に芋川沿いでは全てではないにしても， いくつかの地すべり地形斜面が再滑動して被害をもたら している。地すべり地形斜面の危険度評価とともに，再 滑動した地すべり土塊（地すべり移動体）の移動・堆積 範囲などの運動予測も重要な課題となっている。

本研究では上記の観点から現地調查および地震発生前 後の地すべり分布図による地形解析により, 今回の地震 により発生した地すべり・崩壊に地すべり地形斜面がど の程度関与しているのか，その実態を明らかにするとと もに，地すべり移動体が再滑動した場合，最初の地すべ り地形斜面形成時の滑動と同じょうな運動特性を呈する のかどうかなどを検討した。

\section{2. 調查地域の概要}

調査地域を図 - 1 に示す。本地域は, 新潟県古志郡旧 山古志村を中心に東西約 $12.8 \mathrm{~km}$ ，南北約 $10.7 \mathrm{~km}$ の矩形 の範囲である。本研究では地すべり地形斜面の危険度評 価を目的にしているので，調査範囲の選定については， 今回の中越地震による地すべり・崩壊が多発しているこ とに加えて，その対象となる地すべり地形斜面が数多く 分布していることを条件とした。この調查地域に分布す る地すべり地形斜面数は後述するように 1,500 箇所を超 えている。図中の泛印は震央（緯度37.29, 経度138.87, 深さ $13 \mathrm{~km} ）$ を表す。

図-2に調查地域の地質とその構造（柳沢ら，1986； 小林ら，1991）を示す。調查地域に分布する地質は主に 新生代新第三紀鮮新世の地質年代に位置し，下部から荒 谷層（主に暗灰色塊状泥岩），川口層下部（砂岩優勢砂 岩泥岩互層，デイサイト質火山角砂岩)，川口層上部 (泥 岩優勢砂岩泥岩互層，砂岩）からなる。中越地方は活褶 曲帯と呼ばれ，地殼運動の激しい地帯である。調査地域 には北北東一南南西方向に西側から，東山背斜軸，金比 羅向斜軸，峠背斜軸，梶金向斜軸，小松倉背斜軸が交互 に存在するほか，北部中央付近にはこれらの背斜軸と平 行に鋸山断層が走っている。

本地域をはじめ新潟県は国内でも有数の地すべり多発 地帯として知られている。毎年，豪雨期や融雪期には地 すべり活動が活発になり，多大な被害を被っている。県 内の災害をもたらした地すべりの統計（南木ら，2002） によると, 最近19年間の地すべり発生件数は 1,387 件で,

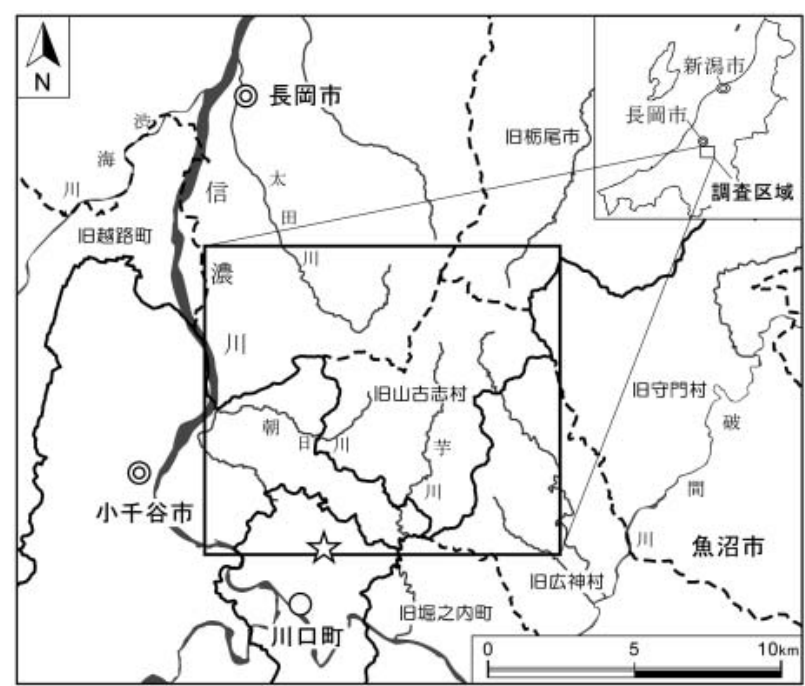

図一 1 調査地域（乞印は震央）

Fig. 1 The survey area (聍: Epicenter)

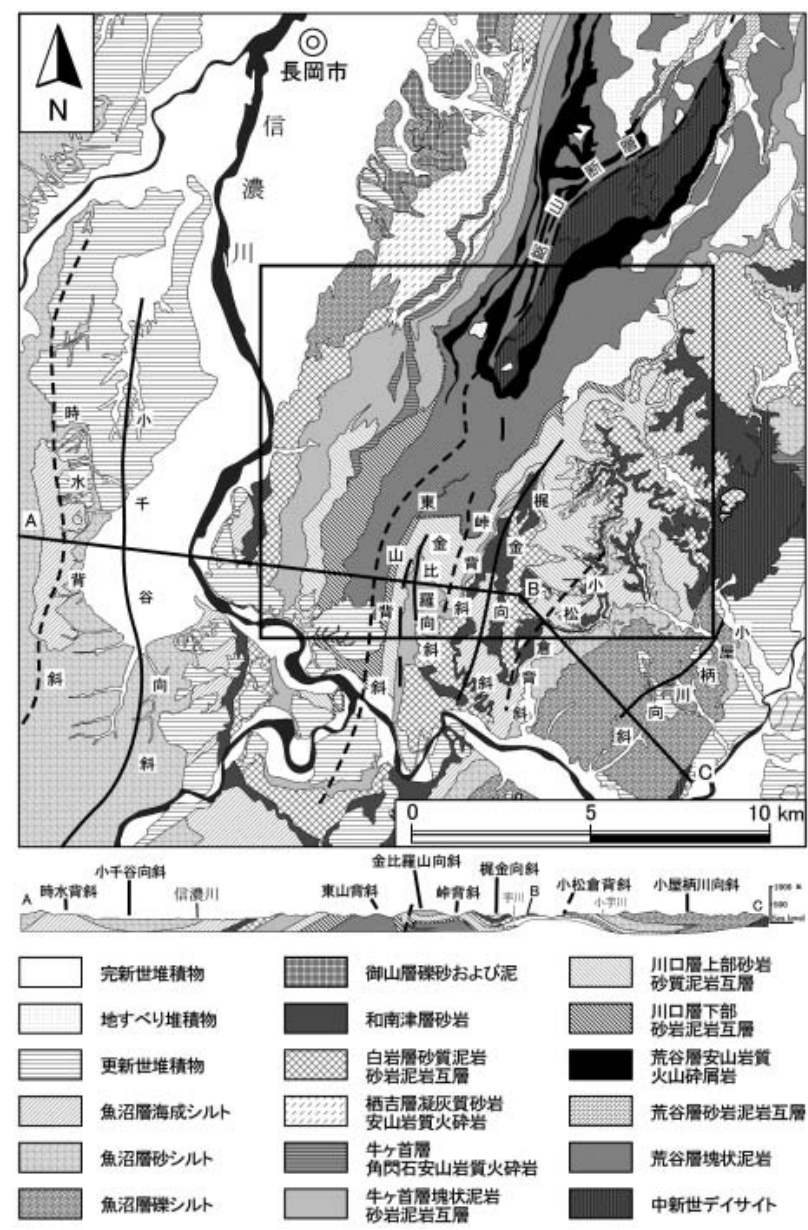

図－２中越地方の地質構造（柳沢ら，1986，小林ら，1991 の図を修正，加筆）

Fig. 2 Geological structure in the Chuetsu region (after Yanagisawa et al., 1986 and Kobayashi et al., 1991)

そのうち $82.8 \%$ が新第三紀の堆積岩層の地域で発生して いる。また，県内の地すべり平均幅は $64.4 \mathrm{~m}$ ，平均長さ は106. $5 \mathrm{~m}$, 地表傾斜は $15^{\circ} \sim 20^{\circ}$ と $25^{\circ} \sim 30^{\circ}$ に頻度分布 
のピークがあり, $35^{\circ}$ 以下での地すべりの発生が全体の 90\%を占めている。地すべりの誘因は降雨（635件， $54.2 \%)$ と融雪 $(752$ 件, $45.8 \%)$ で二分され，新潟県内 では地震による地すべり・崩壊災害が発生したのは少な くともこの 20 年間で今回が初めてとなる。

図 -3 は調査地域内の地すべり地形斜面の分布状況を 表している（防災科学技術研究所，2004）。地すべり地 形斜面は，東部の一部（白岩層）を除いてほぼ全山地地 域に分布し，地すべり活動が地形発達の大きな営力と なっていることがうかがえる。特に図幅中央右付近から 中央下部にかけての芋川沿いの寺野－東竹沢地区，なら びに図幅中央下部の木沢，塩谷地区には規模の大きな地 すべり地形が数多く存在する。

\section{3. 平成16年新潟県中越地震により発生した地すべりの 概要}

今回の地震による中越地方の地すべり・崩壊の発生状 況についてはすでに詳細な調査がいくつかなされている (千木良，2004; 大八木ら，2005; Sato et al., 2005 ; 石 井ら，2005；関口・佐藤， 2006 ; 八木ら，2006；八木ら， 2007など)。本章では主にそれらの既往論文や著者らが 調査した資料などをもとに，本調查地域における地すべ り・崩壊の特徵や誘因との関係を概観する。

\section{1 地震発生後の地すべり分布と崩壊タイプ}

図－4は八木ら（2006）が中越地震後に作成した新規 の地すべり・崩壊の分布図から図 - 3 と同じ調査範囲を 切り出して表示したものである。関口・佐藤（2006）が

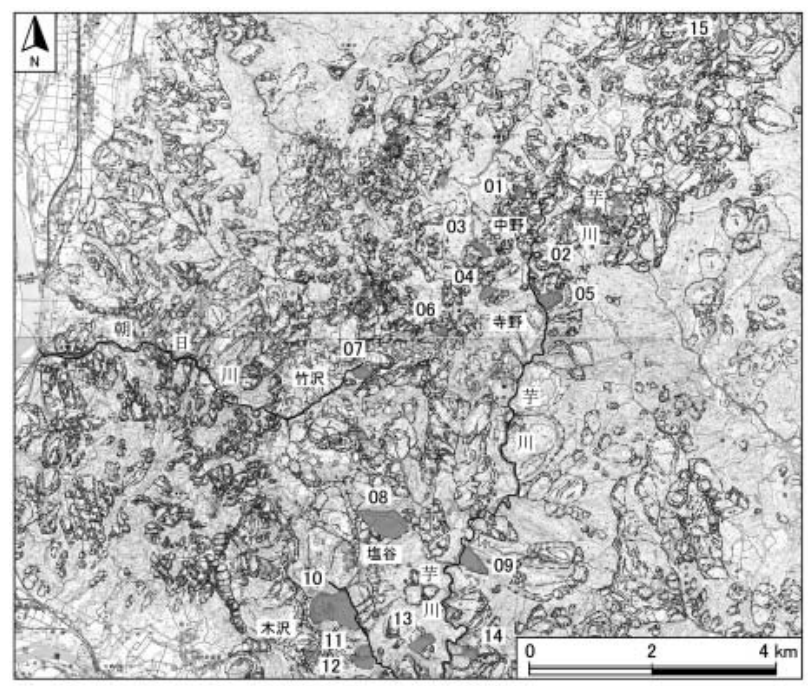

図一 3 調查地域内の地すべり地形斜面の分布 (地震発生前) (地すべり地形分布図「長岡・高田」の一部，防災 科学技術研究所, 2004に主な地名等を加筆)

図中の番号は表 -2 の地すべり番号，灰色の領域は 地すべり地形の範囲を示す。

Fig. 3 Distribution of old landslides in the survey area (after the landslide map "Nagaoka \& Takada”, NIED, 2004)

The numbers and the grayish colored areas refer to the landslides listed in Table2.
指摘しているように芋川流域と東山背斜軸より西側の地 域で密集していることがわかる。一方，図幅の右上部， 右下部，左上部付近は地すべり地形斜面が多い地域にも かかわらず（図-3），今回の地震による地すべり・崩 壊の発生は少ない。この一因として震央から遠いことが 考えられる。Sato et al.(2005) は，斜面崩壊分布は岩質 の違いよりも褶曲構造を有する第三紀層の流れ盤構造に 依存すると報告している。千木良（2004）は地すべり ・ 崩壊の形態を 1）大規模地すべり，2）風化物と崩積土 の崩壊，3）谷埋め土石の流動化，4）表層崩壊の 4 つの タイプに分けてそれぞれ特徴を述べている。

\section{2 地震動と地すべり発生との関係}

防災科学技術研究所（2006b）の小千谷観測点では, 当時, $1,500 \mathrm{gal}, 136 \mathrm{~cm} / \mathrm{s}$ という地震動が観測されてい る。石井ら（2005）は今回の地震による推計震度分布図 と地すべり・崩壊箇所の分布図の重ね合わせを行ってい る。その結果，地すべり・崩壊は推計震度 6 強以上の地 域に多く分布する傾向が認められるが，推計震度 7 以上 の地域にさらに数多く集中する傾向は認められないこと, ならびに南北，東西方向の加速度よりも，上下成分の加 速度の大きな地域で地すべり・崩壊が多発する傾向が見 られたと報告している。

\section{3 先行降雨の影響}

今回の地震発生 3 日前の 2004 年10月20日に長岡市で日 降水量 $102 \mathrm{~mm}$ の豪雨を記録した（気象庁，2005）。10月 の地震発生前まで累積雨量は $227 \mathrm{~mm} に$ 達している。気 象庁（2005）の統計情報（1979-2000）によれば，10月

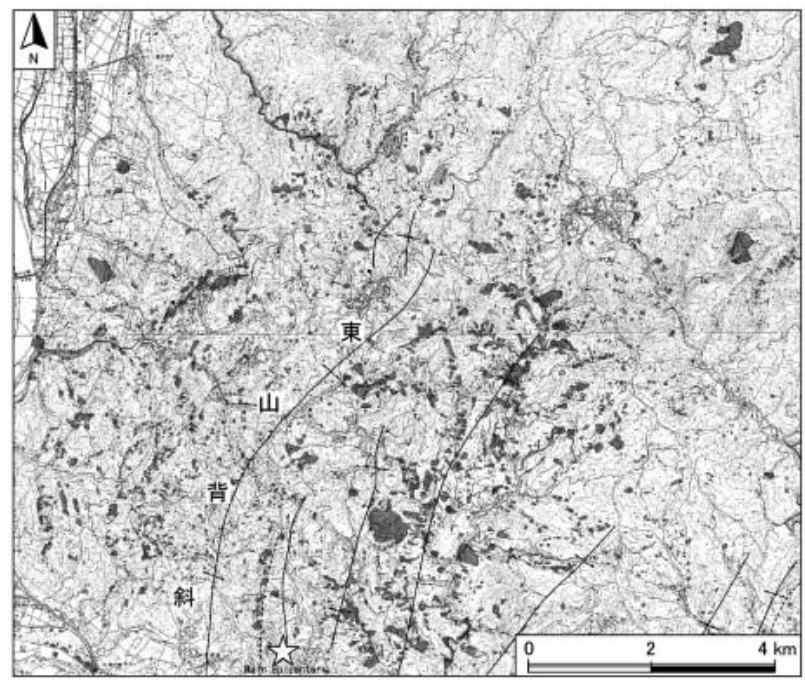

図一 4 平成16年新潟県中越地震による地すべり・崩壊分布 図（八木ら，2006作成図の一部に補筆） 々印は震央を表す。

Fig. 4 Distribution of new landslides triggered by the earthquake in the survey area (after Yagi et al., 2006).

柁: Epicenter 
の日降水量，月降水量の平年值はそれぞれ $6-7 \mathrm{~mm}$, $195 \mathrm{~mm}$ であるので，月降水量としてはそれほど多くな いが，当日の日降水量はきわめて多いものであった。さ らに遡って調べてみると，同年 7 月 13 日の日降水量は 10 月20日の日降水量のほほ 2 倍に相当する $225 \mathrm{~mm}$ を記録 している。その直前の 4 日間で 7 月 $10-13$ 日の累積雨量 は320mmに達しているが，この時点で地すべりや斜面 崩壊が多発した報告はない。したがって，10月20日の降 雨量は単独で崩壊発生を生じるほどの豪雨ではなかった と考えられる。しかし，大量の雨水が斜面土層のすべり 面付近に到達し，飽和層を形成すれば間隙水圧の上昇に より土層のせん断抵抗力は低下し，無降雨状態よりも崩 壊しやすくなる。また，斜面土層が大量の水分を含んで いる場合は滑動とともに地すべり移動体そのものが流動 化しやすくなるので，その拡散度などの変動量調査から ある程度その影響を評価することができる。

\section{4. 地震発生前後の地すべりの発生に関する地形解析}

\section{1 解析手順}

まず，既往の地すべり地形分布図（図－3）から地震 発生前の地すべり地形斜面を選び出し，その位置，発生 数と移動方向の分布を調べた。次いで，地震発生後に作 成された地すべり・崩壊分布図（図－4）を用いて同様 の作業を行い，両者を統計的に比較検討した。解析にあ たって，先述したように地質的要因による局在性を見出 すのは難しいという報告（佐藤ら，2005）もあるので，

本稿では地質区分による検討は除いた。

以下では記述をわかり易くするために，次の用語を用 いる。

「旧地すべり」Old landslide

地震発生前から存在する地すべり地形斜面で，地 すべり地形分布図（図－3）に記載されているもの。 発生誘因および発生年代は不明。

「新規地すべり」New landslide

今回の中越地震により新たに発生した地すべり ・

崩壞。図ー 4 に記載されているもの。

「再滑動地すべり」Reactivated landslide

新規地すべりのうち，旧地すべり区域内で発生し

たもの。地すべり移動体全体が動いたものもあれば， その一部だけが滑ったものも含まれている。

ただし，ここで使っている「地すべり」という用語は， 表層崩壊，岩盤崩落，山腹崩壊など空中写真から読み取 れる斜面変動を包括し，すべり面の深さや運動形態など に基づく仕分けは行っていない。また，「再滑動地すべ り」を厳密に考えると，同じすべり面を有する地すべり 土塊の再滑動を対象にしなければならない。しかし，地 形図上からそれを確認することが困難であることと，本 研究の主目的が地すべり地形斜面と判読されている「旧 地すべり」の危険度を評価することにあるため，ここで は旧地すべり区域内で発生したものを「再滑動地すべり」
とした。

\section{2 旧地すべりおよび新規地すべりの発生状況の比較}

\subsection{1 発生箇所数}

本調査地域内に分布する旧地すべり（地すべり地形斜 面）は表－1に記載されているように，1,517箇所の斜 面に存在する。今回の地震で新規に発生した地すべりは 762箇所，そのうち，旧地すべりの全体，または一部が 滑動した，再滑動地すべりは360箇所で見られた。これ は新規地すべり総数の $47.2 \%$ ，同調査地域に分布する旧 地すべり総数の $23.7 \%$ にあたる。つまり，新規地すべり の約半数弱，旧地すべりの総数の約 2 割強が部分的な崩 壊を含めて再滑動していることになる。しかし，次の 4.2.2節でも述べているとおり，このうち，旧地すべり の地すべり移動体全体が再滑動している割合はさらに低 くなっている（地すべり地形斜面総数の $2.3 \%$ )。地すべ り地形斜面総数に対する発生比率については調査区域の 範囲設定によって左右される点を留意しなければならな いが，この結果からみてもわかるように地すべり地形斜 面の再滑動の発生頻度はそれほど高くなく，すべての地 すべり地形斜面が潜在的に危険な斜面とはいえない。

\subsection{2 再滑動した地すべり地形斜面の崩壊位置によ る分類と発生率}

旧地すべり内で発生した，360箇所の再滑動地すべり は発生位置等により次の 4 タイプに分類できる。図 - 5 はその分類の模式図と発生割合を示している。

(1) 全層崩壊 Full slide（36箇所，10.0\%) 地すべり移動体のほぼ全体が滑動したもの。

(2) 上方崩壊 Scarp slide（51箇所， 14.2\%) 地すべり地形斜面の滑落崖もしくはその上方の未崩 壊斜面が崩壊したもの。主に滑落崖斜面の崩壊が多 い。

(3) 末端崩壊 Toe slide（109箇所，30.3\%) 地すべり移動体の末端の急崖が崩壊したもの。

表- 1 調査区域内の中越地震前後の地すべり発生数の比較 Table 1 Comparison between the number of landslides before and after the earthquake

*The number includes partial slides occurred on the old landslides.

\begin{tabular}{l|c}
\hline \hline \multicolumn{1}{c|}{ 種 類 (Types) } & 箇所数 (Numbers) \\
\hline \hline $\begin{array}{l}\text { A. 旧地すべり } \\
\text { (A. Old landslides) }\end{array}$ & 1,517 \\
\hline $\begin{array}{l}\text { B. 新規地すべり } \\
\text { (B. New landslides) }\end{array}$ & 762 \\
\hline $\begin{array}{l}\text { C. 再滑動地すべり } \\
\text { (C. Reactivated landslides) }\end{array}$ & $360 \%$ \\
\hline \hline $\begin{array}{l}\text { 新規地すべりに対する旧地すべり } \\
\text { の再滑動率 C/B } \\
\text { (Ratio of C to B) }\end{array}$ & $47.2 \%$ \\
\hline $\begin{array}{l}\text { 全旧地すべりに対する再滑動地す } \\
\text { ベりの占める割合 C/A } \\
\text { (Ratio of C to A) }\end{array}$ & $23.7 \%$ \\
\hline \multicolumn{2}{c}{ ※旧地すべり区域内で発生した部分的な崩壊も含む。 }
\end{tabular}




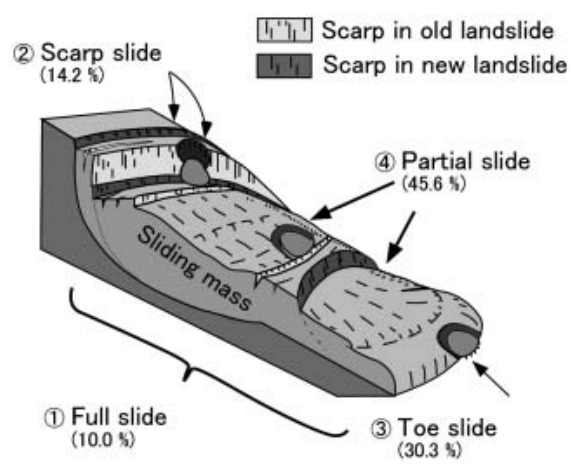

図－5＼cjkstart旧地すべり（地すべり地形斜面）の模式図と再滑動 地すべりのタイプと発生割合

Fig. 5 Schematic figure of old landslide, type of reactivated landslides and their occurrence percentages

(4) 部分崩壊 Partial slide (164箇所，45.6\%)

上記の(1)，(2)，(3)を除く，地すべり移動体の一部が

滑動したもの。広義の意味では(2)と(3)もこれに含ま れる。

この結果から見ると，再滑動した地すべりの約 $44.5 \%$ は，地すべり地形斜面の滑落崖や末端で発生している小 規模な崩壊である。どちらも急勾配を形成している斜面 域である。残りの約 $45.6 \%$ は地すべり移動体内で発生し た部分的なものである。地すべり移動体のほぼ全体が滑 動した事例は再滑動地すべり総数の $10 \%$ あっあた。この 数字は今回の中越地震により発生した地すべり・崩壊総 数（762箇所）の $4.7 \%$ ，同地域に分布する地すべり地形 斜面総数（1,517箇所）の $2.3 \%$ に相当し，再滑動率は低 w。

地すべり移動体の滑動のしやすさは基本的にはその地 すべり土塊が有する安全率で評価される。地すべり地形 斜面はすべり面（脆弱面）が形成されているため, 安全 率が低いという考え方もあるが，第 1 章でも述べたよう にもともと地すべり移動体は崩壊源から滑動して停止し たもので，崩壊後の平均斜面勾配は緩くなり，安定度も 高いという捉え方もできる。森脇（2001）は中越地方で はないが，防災科学技術研究所発行の地すべり地形分布 図「八幡平」図幅を用いて，八幡平地域に分布する地す ベり地形斜面の変動量を計測・解析した結果，いずれの 地すべり地形斜面も崩壊前の前兆過程で停止している地 すべり移動体は見られないと報告している。これは判読 された地すべり地形斜面の大部分が崩壊を生じて滑動し たのち安定勾配に達し，停止したことを意味している。 判読されている地すべり地形斜面は精度の問題もあり, ある程度，変動量の大きなものに限定される点も考慮に 入れなければならないが，今回の地すべり移動体のほぼ 全体が再滑動した割合の低さは，一般に地すべり移動体 の安定度が高いという考え方の優位性を示している。

\subsection{3地すべりの移動方向}

図－6に旧地すべり，新規地すべり，ならびに再滑動 地すべり土塊の移動方向の分布を示す。旧地すべりは西
北一西南の方向にかけて集中している。その他の北一東 一南の方向への移動は見られるものの, 西北一西南の方 向に比較して半数に達していない。今回の地震で発生し た新規地すべりも同じく西北一西南にかけて多く，残り の方向への移動は少ない傾向が見られる。再滑動地すべ りも当然ながら，西北一西南にかけて多く分布し，旧地 すべり，新規地すべりともほぼ一致した傾向を示してい る。

地すべりの発生箇所については，地震動の影響は東西， 南北方向よりも上下動に依存するという報告（石井ら， 2005）や地質要因においても顕著な差異はないという報 告（佐藤ら，2005）を考慮すると，特定の方向に地すべ りが集中するのは地形的要因に依存するものと思われる。 そこで, 地質構造と地形の関係からその要因を検討する。

図 - 7 は762箇所の新規地すべりの移動方向, ならび に東山背斜軸を境に東西両地域に分けて新規地すべりの 移動方向を調べたものである。西側の地域では西向き斜 面が卓越しており，東側の地域では東向きにも移動する 地すべりも見られるが, 西向きに移動する地すべりの数 が圧倒的に多い。同地域には図 -2 に示すように，中央 やや西よりの北北東 - 南南西方向に東山背斜軸が走って いる。これを境に西側の地域では西側に傾斜する単斜構 造を形成しており, 背斜軸と直角方向にあたる西方向 (正 確には西北西方向）に流下する流れ盤型地すべりが多く 発生することが考えられる。一方，東山背斜軸の東側地 域では向斜軸と背斜軸が交互に走っており，地形的には 東西両方向（正確には西北西と東南東方向）に流れ盤型 地すべりが多く存在すると推測できる。このように，東 西両地域における地すべり方向は総じて西方に移動する 地すべりが多い結果になったものと考えられる。

\section{5．再滑動した地すべりの移動・堆積特性に関する検討}

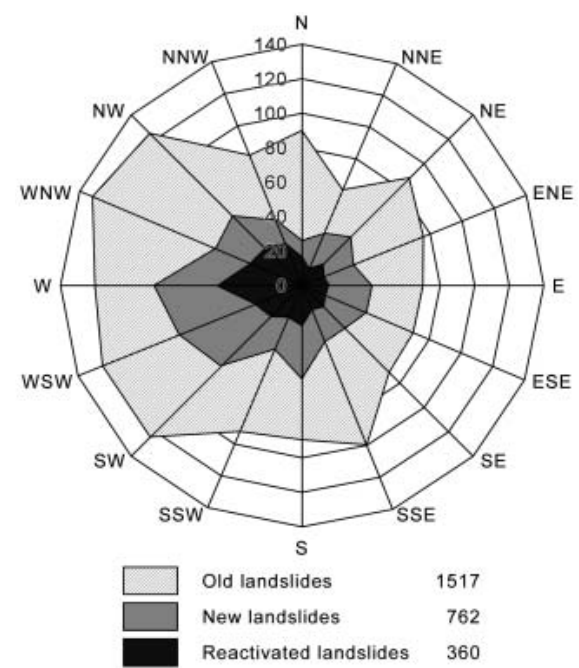

図ー6 旧地すべり，新規地すべりならびに再滑動地すべり の方向性

Fig. 6 Radar chart for the direction of old landslides, new landslides and reactivated landslides 
本章では旧地すべりの地すべり移動体のほぼ全体が滑 動した事例を対象としてその崩壊前後の地形変動解析か ら，地すべり土塊の拡散・伸縮度や等価摩擦係数につい て考察する。前述の全層崩壊タイプ 36 例から, 地すべり 移動体が単体で滑動し，隣接する地すべり移動体にその 滑動が影響されていないものを抽出し（ 9 例，表 - 2 参 照), 図 -3 , 図 -4 を用いて計測した。計測項目は, 旧 地すべりおよび新規地すべりの地すべり移動体に関する 各長さ, 比高, 幅である (図 -8$)$ 。各発生域の脚部の 位置（輪郭）は周辺の滑落崖や側方崖の形状から推定し た。

以下では，地すべり運動を時系列的に区別するため， 旧地すべり，すなわち地すべり地形斜面形成時の運動を 一次すべり (First slide), 今回の地震により再滑動し た地すべりの運動を二次すべり（Second slide）と呼ぶ。 各記号の $\theta, H, L$, の添字の 1 は一次すべり, 2 は二次

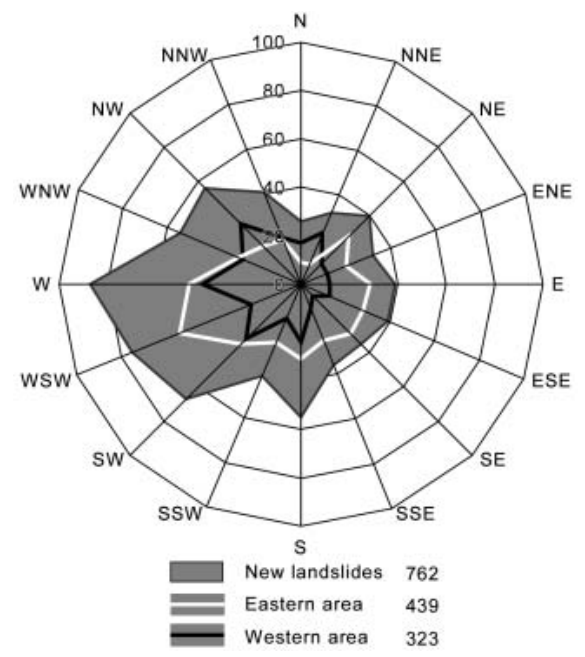

図ー7 新規地すべりの全移動方向ならびに東山背斜軸を境 界とする東西両地域に分布する地すべりの移動方向

Fig. 7 Radar chart for the direction of all new landslides, and the direction of new landslides on the western and eastern areas that categorized by a boundary along the Higashiyama anticlinal axis
すべりを表す。表- 2 中の緯度，経度は一次すべりの移 動体の中央位置を表している。表- 2 で $H_{1} / L_{1}, H_{2} / L_{2}$ （最大垂直高／最大水平移動距離）は，地すべり土塊の 抵抗力が摩擦抵抗だけからなると仮定した場合, 力学的 にはその土塊の動摩擦係数に相当することから等価摩擦 係数と呼ばれ，地すべり・崩壊土塊の流動性を示す指標 として用いられている。この值が小さい場合は流動性が 高いことを示す。Hsü（1975）やScheidegger (1973) ら は, 統計的に崩壊土量が大きくなるとその值は小さくな ると報告している。

この再滑動地すべりは同じ斜面でほぼ同じ規模で発生 したものを対象としているが，一次すべりの地すべり移 動体全体がそのまま正確に再滑動したわけではないので, 一次すべり発生後の地すべり移動体の幅と長さは二次す べり発生前のそれらとはすべてが必ずしも一致していな w。

\section{1 地すべり移動体の崩壊による拡散・伸縮}

図-9は，一次すべり，二次すべりについてそれぞれ 崩壊前後の地すべり移動体の最大幅を計測し，その拡散 の度合いを表したものである。図中の $W s$ は崩壊前の最 大幅 (水平幅), $W a$ は崩壊後の最大幅（水平幅）を示す。 図の直線は $W a=W s$ の関係を示すもので，プロットが この直線より上位に位置すれば，移動前の地すべり幅よ りも拡がったことになる。一次すべりでは幅 $0.46 \mathrm{~km} の$ 地すべり 1 箇所，二次すべりでは，幅 $0.1 \mathrm{~km}$ 付近の地す ベり 2 箇所に大きく拡散したものが見られる。地すべり 移動体の拡散は土塊を構成する材料の物性的な性質と移 動経路付近の地形形状に規定されるため，一義的には決 定できないが，図－9に見られるように全般的には両地 すべりとも横方向の拡散はそれほど激しくない。

一方，図-10は同じく崩壊前後の地すべり移動体の長 さを計測し，その伸縮の度合いを表したものである。図 中の $L s^{\prime}$ は崩壊前の斜面長 (斜面平行長さ), $L a^{\prime}$ は崩壊 後の斜面長（斜面平行長さ）を示す。図の直線は $L a^{\prime}=L s^{\prime}$ の関係を示すもので, 図- 9 と同じくプロット

表一2 解析に使用した再滑動地すべり（一次すべり，二次すべり）の諸元

Table 2 Data used for the analysis of old landslides and reactivated ones

\begin{tabular}{|c|l|c|c|c|c|c|c|c|}
\hline No. & Place of landslides & $\begin{array}{l}\text { Latitude of } \\
\text { First slide } \\
\left(\mathrm{N} 37^{\circ}\right)\end{array}$ & $\begin{array}{c}\text { Longitude of } \\
\text { First slide } \\
\left(\mathrm{E} 138^{\circ}\right)\end{array}$ & $\begin{array}{c}\text { Area of First } \\
\text { slide }\left(\mathrm{km}^{2}\right)\end{array}$ & $\begin{array}{c}\tan \theta_{1} \\
\text { (First slide) }\end{array}$ & $\begin{array}{c}H_{1} / L_{1} \\
\text { (First slide) }\end{array}$ & $\begin{array}{c}\tan \theta_{2} \\
\text { (Second slide) }\end{array}$ & $\begin{array}{c}H_{2} / L_{2} \\
\text { (Second slide) }\end{array}$ \\
\hline 01 & 旧山古志村中野 & $21^{\prime} 27^{\prime \prime}$ & $54^{\prime} 55^{\prime \prime}$ & 0.033 & 0.342 & 0.423 & 0.365 & 0.354 \\
\hline 02 & 旧山古志村中野 & $21^{\prime} 24^{\prime \prime}$ & $55^{\prime} 07^{\prime \prime}$ & 0.008 & 0.425 & 0.401 & 0.342 & 0.341 \\
\hline 03 & 旧山古志村寺野 & $20^{\prime} 31^{\prime \prime}$ & $55^{\prime} 16^{\prime \prime}$ & 0.061 & 0.288 & 0.314 & 0.289 & 0.228 \\
\hline 04 & 旧山古志村竹沢 & $19^{\prime} 51^{\prime \prime}$ & $53^{\prime} 10^{\prime \prime}$ & 0.021 & 0.354 & 0.381 & 0.380 & 0.339 \\
\hline 05 & 旧山古志村東竹沢 & $18^{\prime} 13^{\prime \prime}$ & $54^{\prime} 22^{\prime \prime}$ & 0.082 & 0.281 & 0.299 & 0.262 & 0.174 \\
\hline 06 & 川口町木沢 & $17^{\prime} 45^{\prime \prime}$ & $53^{\prime} 02^{\prime \prime}$ & 0.048 & 0.284 & 0.323 & 0.526 & 0.403 \\
\hline 07 & 川口町木沢 & $17^{\prime} 25^{\prime \prime}$ & $53^{\prime} 14^{\prime \prime}$ & 0.019 & 0.503 & 0.466 & 0.417 & 0.279 \\
\hline 08 & 小千谷市塩谷 & $18^{\prime} 31^{\prime \prime}$ & $53^{\prime} 25^{\prime \prime}$ & 0.192 & 0.244 & 0.263 & 0.321 & 0.320 \\
\hline 09 & 小千谷市塩谷 & $17^{\prime} 25^{\prime \prime}$ & $54^{\prime} 21 "$ & 0.018 & 0.326 & 0.265 & 0.229 & 0.258 \\
\hline
\end{tabular}



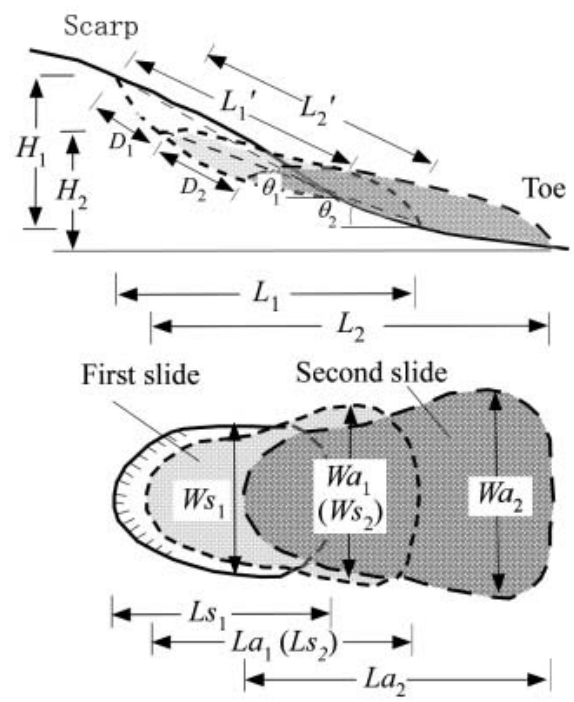

図ー8＼cjkstart地すべり地形斜面の計測要素（ハッチ部が地すべり 移動体)

Fig. 8 Measurement parameters of landslide mass (Hutch part : displaced landslide mass)

がこれより上位に位置すれば，崩壊前の斜面長よりも伸 びたことになる。一次すべりでは斜面長の大きい地すべ りでやや伸びた事例もあるが，おおむねほほ伸縮もなく 移動していることがわかる。二次すべりでは斜面長が 0.3 〜0.4kmのもので少し伸びているものも見られるが，全 体として大きな変化はほぼ見られない。むしろ，寺野地 区では移動土塊が対岸まで到達して，長さ方向に縮小化 したと報告されている（八木ら，2007）。

図-9，10から，本地域の地すべりは一次すべり，二 次すべりとも概して地すべり移動体の長さ・幅を保ちな がら移動している。つまり，地すべり土塊はひと塊の移 動体として移動しているといえる。今回の東竹沢地区の 現地調査では，地すべり移動体上の樹木が立木のまま移 動している様相もみられている。上述の結果はこのよう な動きとも符合する。また，前述したように中越地震の 発生 3 日前の 10 月 20 日に日降水量は $102 \mathrm{~mm}$ （最大時間 雨量 $11 \mathrm{~mm} / \mathrm{hr}) ， 10$ 月の地震発生前までの累積雨量は $227 \mathrm{~mm}$ に達しているが，地すべり土塊そのものが流動 化（擾乱）するほどの大量の水分量は含んでいなかった と推測する。

\section{2 地すべり移動体と等価摩擦係数}

\subsection{1 地すべり移動体の等価摩擦係数と斜面勾配}

先述のHsü，(1975）やScheidegger（1973）らは，等 価摩擦係数と崩壊土量との関係を明らかにしているが, 事前に崩壊土量を見積もることは難しいという問題があ る。これに対して，森脇（1987）は，地すべりや崩壊土 塊の等価摩擦係数が崩壊源の平均斜面勾配に比例するこ とを統計的に見出した。崩壊源の平均斜面勾配は事前に 地形図上で判読できるので崩壊土量を指標とするよりも 応用性がある。この関係式が誘因や地質などに関係なく 成立することから，地すべりや崩壊土塊の流下距離の概

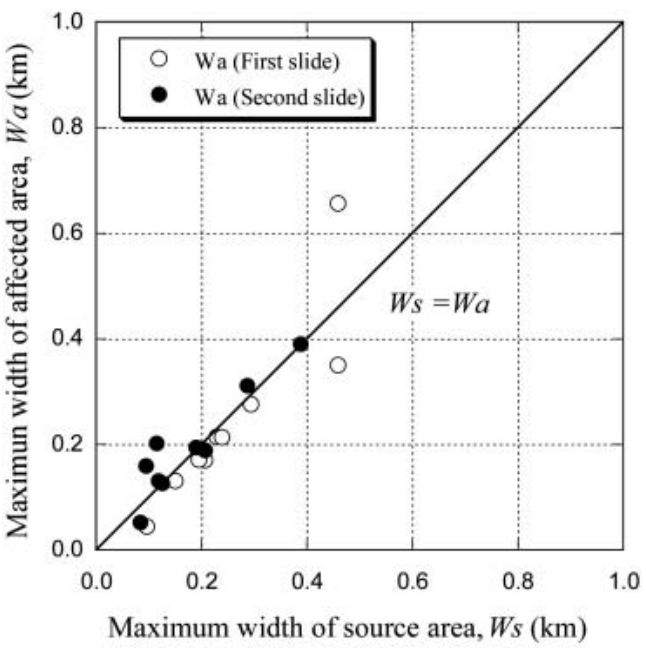

图ー9＼cjkstart地すべり移動体幅の崩壊前後の比較

白丸印は一次すべり（旧地すべり），黒丸印は二次 すべり（再滑動地すべり）。

Fig. 9 Ratio of the width of landslide mass before the slide to that after the slide

White circles: the first slides (old landslides), black circles: the second slides (reactivated landslides).

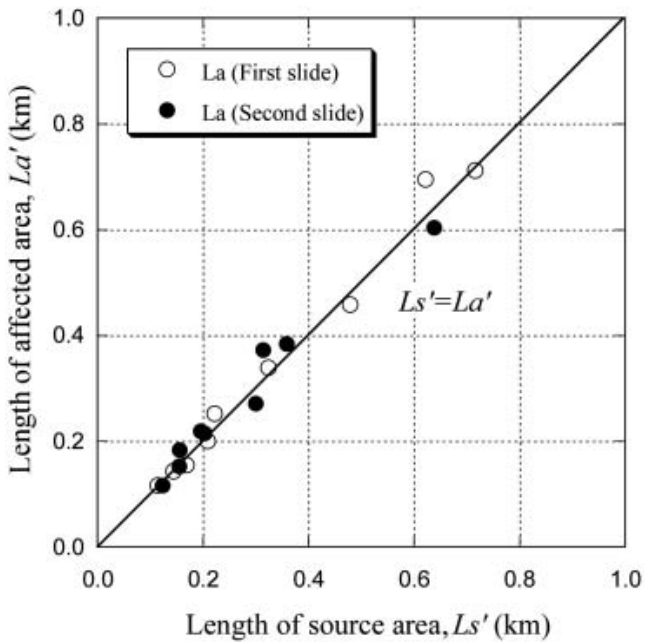

図ー10＼cjkstart地すべり移動体長さの崩壊前後の比較

白丸印は一次すべり（旧地すべり），黒丸印は二次 すべり（再滑動地すべり）

Fig. 10 Ratio of the length of landslide mass before the slide to that after the slide

White circles : the first slides (old landslides), black circles: the second slides (reactivated landslides).

略予測手法を提唱している。また，森脇・八反地 (2002) は第三紀層や第四紀火山体，破砕带における地すべり地 形斜面の等価摩擦係数を調べ，それぞれ係数は異なるも のの，やはり崩壊源の平均斜面勾配に比例することを明 らかにしている。今回は一次すべりと二次すべりとでは 等価摩擦係数と平均斜面勾配との関係は異なるのかどう かを検討した。

\section{2 .2 一次すべり, 二次すべりの等価摩擦係数}

図-11は一次すべり（○印），二次すべり（の印）に おける，それぞれ両者の関係を表したものである。本調 査地域の一次すべり（○印）の場合も，等価摩擦係数は 
(1)式で表されるように崩壊源の平均斜面勾配と比例関係 にある（図－11の実線）。(1)式の $R^{2}$ は決定係数を表す。

$$
H_{1} / L_{1}=0.76 \tan \theta+0.09 \quad\left(R^{2}=0.716\right)
$$

これは(2)式に示す山形県清川地すべりの第三紀層地す ベりの関係式（森脇・八反地，2002）とほぼ同じ傾向を 示している。

$$
H / L=0.76 \tan \theta+0.03 \quad\left(R^{2}=0.730\right)
$$

一方，今回の中越地震により発生した二次すべりの分 布（○印）を見ると，回帰直線（図－11の一点鎖線）は 一次すべりとほぼ同じ勾配を示すが，流動性の高い地す ベりも存在するため，切片は一次すべりよりもさらに下 方に位置し, 全体的に流動性は高くなっている。データ の分散も一次すべりに比較して大きい。

$$
H_{2} / L_{2}=0.60 \tan \theta+0.09 \quad\left(R^{2}=0.573\right)
$$

今後の地すべり対策などを考えれば，最大移動距離が 推定できる下限值を考慮したほうが良い。そこで，図一 11の下限に位置するNo.5，No.6，No.7から，(4)式で表 される下限式（図-11の破線）を求めた。

$$
H_{2} / L_{2(\text { Lower })}=0.756 \tan \theta-0.38
$$

上記の(1)，(2)，(3)，(4)式はいずれも崩壊高さに対する 移動距離の比は崩壊源の斜面勾配に比例する形で表され ている。これらの式を用いて図式解法により崩壊源の平 均斜面勾配からおよその移動距離を推定できる（森脇, 1987)。このように一次すべり，二次すべりのいずれに しても，統計的には有意な傾向を示しており，本調査域 の今後の地すべり地形斜面の再滑動にともなう被災域の 予測について，ひとつの手がかりを得ることができた。 特に二次すべりについては，(4)式で表される下限式を用 いることによって地すべり対策上，より安全側の移動距 離が推定できる。

\subsection{3 流動性の高い地すべりの発生要因}

二次すべりの中には山麓を流れる渓流まで移動した東 竹沢地区（No.5）や寺野地区（No.3）などで流動性の 高い地すべりが存在している（表－2）。これらの発生 要因については現在までのところ決定的な説はないが, 地形的要因と土質力学特性の両面から合理的に考えられ る。地形的要因については，長年月にわたる河川の下刻 作用による影響が挙げられる。今回再滑動した地すべり は渓流に面している流れ盤型地すべりが多い。河川水の 流れにより地すべり地形斜面の下端が侵食され，地すべ り斜面全体の安全率が低くなっていたこと，ならびに対 岸まで障害物がなかったことなどが考えられる。土質力 学的な面については現地試料を採取して地震時リングセ ン断試験を行った佐々（2007）らの研究がある。彼らに よると，両地区の地すべりともすべり面境界層である砂 層のセン断に伴う土粒子の粉砕と過剰間隙水圧の上昇に

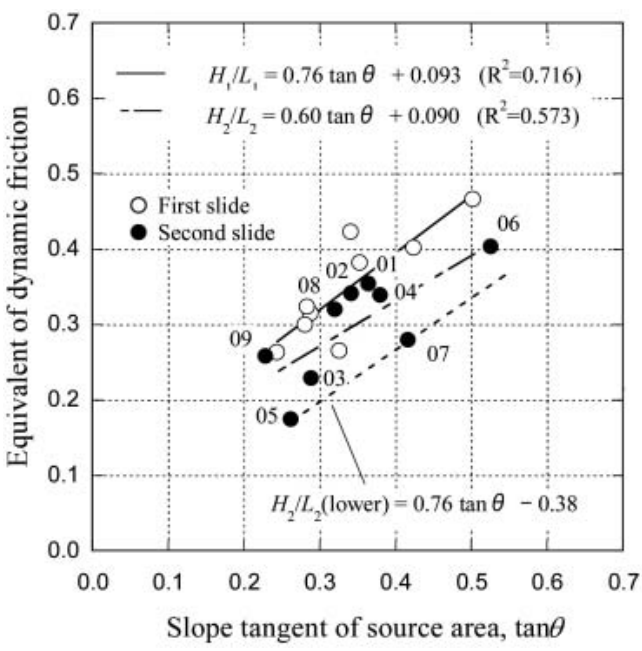

図-11 崩壊源の平均斜面勾配と等価摩擦係数

白丸印は一次すべり（旧地すべり），黒丸印は二次 すべり（再滑動地すべり）を表す。図中の黒丸印の 番号は表 -1 , 図 -3 参照。

Fig. 11 Relationship between the equivalent coefficient of friction and average slope on the source area White circles: the first slides (old landslides), black circles: the second slides (reactivated landslides). The numbers on the black circles refer to Table 1 \& Fig. 3

よるすべり面液状化説を唱え，流動性の高い地すべりで あったことを指摘している。10月20日の先行降雨に加え て, 地震動, 土質的・地形的条件などの複合的な要因が 相俟って流動性が高くなったものと考えられる。

\section{6. まとめ}

本稿では，中越地震による地すべり地形斜面の再滑動 に焦点をあてて，新潟県旧山古志村を中心に調査地域を 設定し，地震発生前後の地すべり発生状況を比較検討し た。その調査結果をまとめると，以下のようになる。

(1) 地すべり地形斜面および中越地震による地すべりの 発生はおおむね西向き斜面に多く見られた。これは， 調査地域の東山背斜軸を境界とする西半分で西向き の単斜構造，東半分では東西両方向の斜面が形成さ れる褶曲構造を反映しているためであると考えられ る。

（2）今回の地震により発生した地すべり・崩壊総数 $(762$ 箇所）の $47.2 \%$ が地すべり地形斜面区域内で発生し ている。その大半が部分的な崩壊で滑落崖や斜面末 端の急斜面で発生しているものも多い。ほぼ全体が 再滑動した箇所数は地震で発生した地すべり・崩壊 総数の $4.7 \%$ あっあた。この数字から見ると，本調 查地域では地すべり移動体全体が再滑動する確率は かなり低いといえる。

（3）地すべり移動体のほぼ全体が再滑動した地すべりに ついて新旧移動体の変動量を計測した結果，地すべ り地形斜面形成時（一次すべり）も再滑動時（二次 すべり）のどちらも土塊の伸縮・拡散の割合は小さ 
く，ひと塊の地すべり移動体として移動している。

（4）地すべり移動体のほぼ全体が再滑動した新旧地すべ りの等価摩擦係数を調べた結果，一次すべりも二次 すべりも崩壊源の平均斜面勾配と明暸な比例関係に あることが明らかになった。この関係式を用いるこ とにより，今後，当地域で滑動が想定される斜面の 平均勾配からおよその土塊の移動距離を推測するこ とができる。

\section{7. おわりに}

ここでは, 地すべり地形斜面の再滑動の実態とその運 動特性を明らかにするため, 地震発生前後の地すべり土 塊の変動量を計測・解析した。その結果，限られた範囲 であるが地すべり地形斜面の再滑動率やその運動特性を ある程度，数量的に評価することができた。現在，独防 災科学技術研究所では地すべり地形分布図の全国網羅を 目標に判読作業を進めている。その作成にとどまらず, 次のステップとしてそれぞれ判読された地すべり地形斜 面の危険度評価を行うことが防災対策に極めて重要であ ることを改めて痛感した。

また，今回の地震では，地すべり移動土塊が溪流を閉 塞し, いくつかの集落が水没したほか, その地すべりダ ムの破壊による土石流化を懸念して下流の住民が避難を 余儀なくされるなど，これまでに見られなかった地すべ り災害の様相を呈した。これは個々の地すべり斜面のみ を対象とした従来型の対策だけではなく，地すべりダム の形成・破壊も考慮に入れた，流域全体の土砂災害対策 をたてねばならないことを示唆している。地すべり対策 研究の新たな課題である。今後もデー夕を収集・解析し, 地すべり地形斜面の危険度評価・運動予測を対象とした 実用的な防災研究を進めたい。

\section{謝辞}

本解析にあたって，山形大学教授 八木浩司氏ならび に国土防災技術株式会社 山崎孝成氏には中越地震発生 後に作成された精緻な地すべり・斜面崩壊分布図の原図 を快く使わせていただいた。心より御礼申し上げます。 また，本稿をまとめるにあたって，独防災科学技術研究 所 福直輝旗氏ならびに元高知大学教授 日浦啓全氏に は的確な助言をいただいた。京都大学防災研究所助教の 王 功輝氏には英文校閲を扔願いした。ここに記して皆 様方に感謝の意を表します。

\section{引用文献}

独防災科学技術研究所 (2004)：地すべり地形分布図 第17集「長 岡・高田」, 研究資料第 244 号.

独防災科学技術研究所 (2006a) : 地すべり地形分布図データベー ス, http://lsweb1.ess.bosai.go.jp/jisuberi/jisuberi_mini/index. asp

独防災科学技術研究所 (2006b) : 近地地震動記録による新潟県中 越地震の震源インバージョン, http://www.k-net.bosai.go.jp /k-net/topics/niigata041023/.
千木良雅弘（2004）：2004年中越地震による東山丘陵斜面災害につ wて - 地質 - 地形的特徵 - 文部科学省科学技術振興調整費 平成16年 (2004) 年新潟県中越地震に関する緊急研究・テー マ2「地震時の土砂災害研究」グループ, 社日本地すべり学 会,（NPO）国際斜面災害研究機構，平成16年新潟県中越地 震による斜面災害緊急シンポジウム講演集，pp. $36-44$.

Hsü K.J.(1975) : Catastrophic debris streams generated by rockfalls, Geological Society of America Bulletin, 86, pp. 129-140.

石井靖雄・野村康裕・藤澤和範・西本晴男・鈴木常正 (2005) : 平 成16年（2004年) 新潟県中越地震により発生した地すべりの特 徵, 第44回日本地すべり学会研究発表会講演集, pp. 15-18.

気象庁 (2005) : 気象統計情報, http ://www.data. kishou. go.jp/ etrn/index.html.

小林嚴雄・立石雅昭・吉岡敏和・島津光夫 (1991)：5 万分の 1 地 質図幅「小千谷」，地質調査所.

南木 均 - 池田則夫 ·高橋亮一 - 植野利康 - 寺尾 亮 - 高梨和 行 - 渡部康弘・白杵伸浩 - 坂井俊介 ・池田伸俊 (2002) : 新潟 県の地すべり災害実態による移動形態，第41回日本地すべり 学会研究発表会講演集, pp. $383-386$.

森脇 寛 (1987)：崩土の到達距離予測, 地すべり, Vol. 24, No.2, pp. $10-16$.

森脇 寛（2001）：地表面移動量を指標とする地すべり斜面の崩壊 危険度評価，地すべり，Vol. 38，No.2，pp.11-18。

森脇 寛・八反地剛（2002）：5 万分の 1 地すべり地形分布図を用 いた地すべり地形解析, 地すべり, Vol. 39, No.2, pp.5462.

大八木規夫・井口＼cjkstart隆・藤田勝代（2005）：2004年新潟県中越地震 による地すべりの主なタイプ, 第44回日本地すべり学会研究 発表会講演集, pp. $5-8$.

大八木規夫・池田浩子（1998）：地すべり構造と広域場から見た澄 川地すべり，地すべり, Vol. 35, No.2, pp.1-10.

佐々恭二・福岡 浩・汪 発武・王 功輝 (2007) : 平成16年新潟 県中越地震により発生した再活動地すべり地における拘束地 すべり発生・流動機構, 日本地すべり学会誌, Vol. 44, No.2, pp. $71-78$.

佐藤 浩- 関口辰夫 - 小白井亮一 - 神谷 泉 - 長谷川裕之 - 鈴木 義宜・飯田誠 (2005) : 中越地震による斜面災害状況図と雪 崩のハザードマップ基碟情報図の作成, 新潟県中越地震に関 する緊急研究 (文部科学省), 研究成果の詳細報告, pp. 114 .

Sato. H., Sekiguchi. T., Kojiroi. R., Suzuki. Y. and Iida. M. (2005) : Overlaying landslides distribution on the earthquake source, geological and topographical data, the Mid Niigata prefecture earthquake in 2004, Japan, Landslides, 2 ( 2), pp. $143-152$.

Scheidegger A. E. (1973) : On the reach and velocity of catrastrophic landslides, Rock Mechanics, 5, pp. 231-236.

関口辰夫・佐藤 浩 (2006) : 新潟県中越地震における斜面崩壊の 特徵と分布, 日本地すべり学会誌, Vol. 43, No.3, pp. 1426.

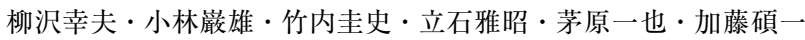
(1986)： 5 万分の 1 地質図幅「小千谷」，地質調查所.

八木浩司・山崎孝成・守岩 勉・山科真一 (2006)：地すべり学会 ホームページ, 2004年新潟県中越地震にともなう地すべり・崩 壊分布図一その特徵と詳細判読事例 - (2006修正版), http : / /japan.landslide-soc.org/

八木浩司・山崎孝成・渥美賢拓 $(2007) ： 2004$ 年新潟県中越地震に ともなう地すべり・崩壊発生場の地形・地質的特徵のGIS解 析と土質特性の検討, 日本地すべり学会誌, Vol. 43, No. 5, pp. $44-55$.

米谷恒春・森脇 寛・清水文健（1983）：1982年台風第10号と直後 の低気圧による三重県一志郡の土石流災害拉よび奈良県西吉 野村和田地すべり災害調査報告, 国立防災科学技術センター (現防災科学技術研究所) 主要災害調査, 第 22 号, $70 \mathrm{p}$. （原稿受付 2007 年11月 5 日，原稿受理2008年 9 月 5 日） 